\title{
PEMBELAJARAN KONTEKSTUAL: Mencapai Hasil Belajar yang Optimal
}

\author{
Mia Audina* \\ E-mail: mia.audina5811@student.unri.ac.id \\ * Program Studi Pendidikan Bahasa dan Sastra Indonesia, Universitas Riau
}

\section{Pengantar}

Permasalahan pendidikan saat ini salah satunya ialah proses pembelajaran yang lemah. Proses pembelajaran umumnya masih berfokus pada guru sebagai sumber utama pengetahuan (Kadir, 2013). Proses pembelajaran merupakan salah satu kunci untuk mencapai tujuan pendidikan. Kebanyakan siswa menganggap mata pelajaran yang dijelaskan di sekolah itu sulit sehigga tidak jarang seorang siswa sudah terlebih dahulu merasa kurang mampu untuk mempelajarinya (Sakkashiri, 1991). Hal tersebut bisa saja terjadi dikarenakan oleh kegiatan pembelajaran yang menggunakan metode teacher-centered yang tidak dapat menarik perhatian siswa karena siswa tidak tertarik dan bosan. Keadaan ini akan merugikan terhadap keberhasilan siswa bila tidak segera dibenahi (Manalu dkk., 2016).

Agar dapat memunculkan semangat belajar dari siswa peran pendidik disini ialah meningkatkan kemauan siswa mencari hubungan konseptual antara pengetahuan yang dimiliki dengan yang dipelajari di dalam kelas (Silaban \& Dewi, 2012). Untuk mencapai tujuan ini maka diperlukan suatu tindakan konkrit yang efisien berdasarkan pengetahuan dan kemampuan yang dibutuhkan dalam proses pembelajaran, yang dapat menyebabkan terjadinya pergeseran pembelajaran yang membosankan menjadi sangat menarik untuk dipelajari oleh siswa (Rosalia et al., 2019).

Proses belajar menuntut siswa untuk aktif mencari, menemukan dan menggunakan pengetahuan yang dimiliki untuk mendapatkan suatu konsep pelajaran dengan bantuan guru. Pengajaran yang efektif adalah pengajaran yang menyediakan kesempatan belajar atau melakukan aktivitas sendiri. Aktivitas belajar 
adalah suatu kegiatan yang dilakukan oleh siswa pada saat proses pembelajaran untuk mencapai hasil belajar. Untuk mencapai hasil belajar yang optimal dalam pembelajaran perlu ditekankan adanya aktivitas siswa baik secara fisik, mental, intelektual, maupun emosional (Hamalik, 2001). Salah satu metode yang dapat memberdayakan peserta didik adalah pendekatan kontekstual (Johnson, 2007; Kadir, 2013; Amir, 2015; Manalu dkk., 2016).

Menurut teori Dierich dalam Hamalik, (2001) bahwa aktivitas siswa digolongkan dalam beberapa aktivitas antara lain: (1) Aktivitas visual; (2) Aktivitas lisan (oral); (3) Aktivitas mendengarkan; (4) Aktivitas menulis; (5) Aktivitas menggambar; (6) Aktivitas metrik; (7) Aktivitas mental; dan (8) Aktivitas emosional. Dalam pandangan dunia pendidikan bahwa siswa yang berpartisipasi secara aktif, maka ia akan memiliki ilmu pengetahuan yang baik (Slameto, 2010).

Pembelajaran kontekstual merupakan pembelajaran yang menekankan keterkaitan antara materi pelajaran dengan kehidupan nyata yang mereka hadapi (Silaban \& Simangunsong, 2015; Manalu dkk., 2016). Pembelajaran ini menyajikan situasi belajar yang alami, menuntut keaktifan siswa dalam menyelidiki dan bekerja sama dengan siswa lain. Pembelajaran kontekstual mendorong siswa untuk dapat membuat hubungan antara pengetahuan yang dimilikinya dengan kehidupan seharihari, serta mampu membangun konsep-konsep pengetahuan yang mereka dapat dari proses belajar (Elvinawati, 2008; Muchtar et al., 2020).

\section{Tindakan yang Dilakukan}

\section{a. Minat Belajar Siswa}

Setiap proses pembelajaran tentunya diharapkan peserta didik memperoleh hasil belajar yang baik. Namun pada kenyataannya hasil belajar yang diperoleh siswa tidak selalu baik dan sesuai harapan. Sebagaimana yang menjadi standar baik atau tidaknya hasil belajar atas dasar KKM yang telah ditetapkan sebagai patokan keberhasilan proses pembelajaran. Hal ini harus menjadi perhatian dan bahan evaluasi dalam proses pembelajaran. Hasil belajar siswa yang belum baik menjadi salah satu permasalahan dalam pendidikan. Hasil belajar siswa menunjukkan kemampuan dan kualitas siswa sebagai dampak dari proses pembelajaran yang telah dilaluinya. Melton menyiratkan bahwa hasil belajar merupakan tindakan dan 
pertunjukan yang mengandung dan mencerminkan kompetensi peserta didik yang berhasil menggunakan konten, informasi, ide-ide dan alat-alat dalam pembelajaran. Oleh karena itu hasil belajar dapat didefenisikan sebagai kompetensi dan keterampilan yang dimiliki siswa setelah masa pembelajaran (Molstad \& Karseth, 2016).

Hasil belajar siswa masi bisa dikatakan belum optimal. Hal tersebut tercermin dari hasil belajar siswa yang belum mencapai standar KKM. Pertanyaan yang timbul dari permasalahan tersebut adalah mengapa hasil belajar siswa belum optimal?. Merujuk pada perspektif teori belajar bahwasannya banyak faktor yang mempengaruhi hasil belajar siswa, baik secara internal maupun eksternal. Faktor internal diantaranya adalah minat belajar yang diduga kuat mempengaruhi hasil belajar siswa.

Menurut oleh (Slameto, 2010) belajar dapat diukur melalui empat indikator, yaitu ketertarikan untuk belajar, perhatian dalam belajar, motivasi belajar dan pengetahuan. Ketertarikan untuk belajar diartikan apabila seseorang yang berminat terhadap suatu pelajaran maka ia akan memiliki perasaan ketertarikan terhadap pelajaran tersebut. Ia akan rajin belajar dan terus memahami semua ilmu yang berhubungan dengan bidang tersebut, ia akan mengikuti pelajaran dengan penuh antusias dan tanpa ada beban dalam dirinya. Perhatian merupakan konsentrasi atau aktivitas jiwa seseorang terhadap pengamatan, pengertian ataupun yang lainnya dengan mengesampingkan hal lain dari pada itu. Jadi siswa akan mempunyai perhatian dalam belajar, jika jiwa dan pikirannya terfokus dengan apa yang ia pelajari. Motivasi merupakan suatu usaha atau pendorong yang dilakukan secara sadar untuk melakukan tindakan belajar dan mewujudkan perilaku yang terarah demi pencapaian tujuan yang diharapkan dalam situasi interaksi belajar. Pengetahuan diartikan bahwa jika seseorang yang berminat terhadap suatu pelajaran maka akan mempunyai pengetahuan yang luas tentang pelajaran tersebut serta bagaimana manfaat belajar dalam kehidupan sehari-hari.

\section{b. Pembelajaran Kontekstual}

Beberapa pendapat para ahli mengenai pengertian Pembelajaran Kontekstual, Menurut Wina sanjaya (2005: 109) pembelajaran kontekstual adalah 
suatu pendekatan pembelajaran yang menekankan pada proses keterlibatan siswa secara penuh untuk menemukan materi yang dipelajari dan menghubungkannya dengan situasi kehidupan nyata sehingga mendorong siswa untuk dapat menerapkannya pada kehidupan mereka.

Pembelajaran kontekstual menurut Nanik rubiyanto (2010: 72) adalah konsep belajar yang membantu guru mengaitkan materi yang dipelajari siswa dengan situasi dunia nyata dan mendorong siswa untuk membuat hubungan antara pengetahuan yang dimilikinya dengan penerapannya dalam kehidupan sehari-hari.

Menurut Johnson (2002: 67) Pembelajaran kontekstual adalah sebuah proses pendidikan yang menolong para siswa melihat makna di dalam materi akademik yang mereka pelajari dengan cara menghubungi subjek-subjek akademik yang mereka pelajari dengan konteks kehidupan sehari-hari mereka, yakni konteks pribadi, sosial, dan budaya. Hal ini juga diungkapkan oleh Kemendikbud melalui direktorat PSMP (2008: 161) mendefinisikan pembelajaran kontekstual sebagai suatu proses pendidikan yang bertujuan untuk memotivasi siswa untuk memahami makna materi pembelajaran dengan mengkaitkannya pada kehidupan sehari-hari (konteks pribadi, sosial, dan kultural) sehingga siswa memiliki pengetahuan/ketrampilan yang secara fleksibel dapat diterapkan dari suatu permasalahan/konteks ke permasalahan lain.

Berdasarkan pendapat para ahli di atas dapat disimpulkan bahwa Pembelajaran kontekstual merupakan pembelajaran yang menekankan bahwa siswa harus mengetahui implementasi dari pengetahuan yang diperolehnya sehingga pengetahuan tersebut akan bermakna bagi siswa. Pengetahuan yang dimiliki siswa harus memiliki kaitan dengan dunia nyata atau keseharian siswa. Apabila siswa menemukan banyak keterkaitan dalam pembelajaran, maka pengetahuan yang dimilikinya akan semakin bermakna.

\section{Sarana Pendukung}

\section{a. Hakikat Pembelajaran Kontekstual}

Tiga hakikat pembelajaran kontekstual, yaitu (1) menekankan kepada proses keterlibatan siswa untuk menemukan materi, artinya proses belajar diorientasikan pada proses pengalaman secara langsung melalui proses mencari dan 
menemukan sendiri materi pelajaran; (2) mendorong agar siswa dapat menemukan hubungan antara materi yang dipelajari dengan situasi kehidupan nyata, artinya siswa dituntut untuk dapat menangkap hubungan antara pengalaman belajar di sekolah dengan kehidupan nyata. Hal ini sangat penting, sebab dengan dapat mengorelasikan materi yang ditemukan dengan kehidupan nyata, materi itu tidak hanya bermakna secara fungsional, akan tetapi materi yang dipelajarinya akan tertanam erat dalam memori siswa, sehingga tidak akan mudah dilupakan; dan (3) mendorong siswa untuk dapat menerapkannya dalam kehidupan, artinya bukan hanya mengharapkan siswa dapat memahami materi yang dipelajarinya, akan tetapi bagaimana materi pelajaran itu dapat mewarnai perilakunya dalam kehidupan sehari-hari. Materi pelajaran dalam konteks ini bukan untuk ditumpuk di otak dan kemudian dilupakan, akan tetapi sebagai bekal mereka dalam mengarungi kehidupan nyata (Sanjaya, 2006; Suyanti, 2010).

\section{b. Komponen Utama Pembelajaran Kontekstual}

Pembelajaran Kontekstual terdiri dari beberapa komponen utama, yaitu (1) Kontruktivisme (contrucvism) adalah pengetahuan yang dibangun oleh manusia sedikit demi sedikit, yang hasilnya diperluas melalui konteks yang terbatas dan tidak sekonyong-konyong. Pengetahuan bukanlah seperangkat fakta-fakta, konsep, atau kaidah yang siap untuk diambil dan diingat dan mengkontruksi pengetahuan itu dan memberi makna melalui pengalaman nyata; (2) Inkuiri (inquiry) merupakan bagian inti dari kegiatan pembelajaran berbasis kontekstual. Pengetahuan dan keterampilan yang diperoleh siswa diharapkan bukan hasil mengingat seperangkat fakta-fakta, tetapi hasil dari menemukan sendiri. Guru harus selalu merancang kegiatan yang merujuk pada kegiatan menemukan, apapun materi yang diajarkannya; (3) Bertanya (questioning) merupakan strategi utama yang berbasis kontekstual. Bertanya dalam pembelajaran dipandang sebagai kegiatan guru untuk mendorong, membimbing, dan menilai kemampuan berfikir siswa. Kegiatan bertanya merupakan bagian paling penting dalam melaksanakan pembelajaran yang berbasis inquiry, yaitu menggali informasi, mengkonfirmasikan apa yang sudah diketahui, dan mengarahkan perhatian pada aspek yang belum diketahuinya; (4) Masyarakat belajar (learning community). Dalam prosesnya, masyarakat belajar 
bisa terjadi apabila ada proses komunikasi dua arah. Seorang guru yang mengajari siwanya bukan contoh masyarakat belajar karena komunikasi hanya terjadi satu arah yaitu informasi hanya datang dari guru kearah siswa, tidak ada arus informasi yang perlu dipelajari guru yang datang dari arah siswa; (5) Pemodelan (modeling). Dalam pembelajaran kontekstual, guru bukan satu-satunya model. Pemodelan dapat dirancang dengan melibatkan siswa. Seseorang bisa ditunjuk untuk memodelkan sesuatu berdasarkan pengalaman yang diketahuinya. Modeldapat juga didatangkan dari luar yang ahli bidangnya, misalnya mendatangkan seseorang perawat untuk memodelkan cara menggunakan termometer untuk mengukur suhu tubuh pasien; (6) Refleksi (reflection), adalah cara berfikir tentang apa yang baru dipelajari atau berfikir kebelakang tentang apa-apa yang sudah kita lakukan dimasa yang lalu. Siswa mengendapakan apa yang baru dipelajarinya sebagai struktur pengetahuan yang baru, yang merupakan pengayaan atau revisi dari pengetahuan sebelumnya. Refleksi merupakan respons terhadap kejadian, aktivitas, atau pengetahuan yang baru diterima; dan (7) Penilaian sebenarnya (authentic assessment) adalah proses pengumpulan berbagai data yang bisa memberikan gambaran perkembangan belajar siswa (Trianto, 2007).

\section{Tindakan Solutif}

a. Gambaran perkembangan belajar siswa perlu diketahui guru agar bisa memastikan bahwa siswa mengalami proses pembelajaran dengan benar melalui Penilaian autentik menilai pengetahuan dan keterampilan (performance) yang diperoleh siswa.

b. Jika gambaran perkembangan belajar siswa tidak bisa dimaksimalkan penilaian bisa juga oleh teman lain atau orang lain. Karakteristik penilaian autentik antara lain: dilaksanakan selama dan sesudah proses pembelajaran berlangsung; bisa digunakan untuk formatif maupun sumatif; yang diukur keterampilan dan performasi, bukan mengingat fakta; berkesinambungan; terintegrasi; dandapat digunakan sebagai feedback. Dalam penerapannya, pembelajaran dengan pendekatan kontekstual harus menerapkan seluruh koponen tersebut (Trianto, 2007). 
Simpulan

Pembelajaran kontekstual efektif dalam mewujudkan hasil belajar yang merangsang keaktifan belajar dan dapat meningkatkan hasil belajar siswa secara optimal. Keefektifan ini disebabkan keselarasan pembelajaran kontekstual dengan kebutuhan pendidikan saat ini yang diharapkan pengajar dapat mendidik siswa dengan lebih efektif dan evesien. Dimana siswa menjadi masyarakat belajar dan siswa mampu membangun konsep-konsep pengetahuan yang mereka dapat dari proses belajar.

\section{Referensi}

Link google scholar https://scholar.google.co.id/scholar?hl=id\&as_sdt=0\%2C5\&q=manfaat+pe mbelajaran+kontekstual+bagi+siswa + sma\&btnG=\#d=gs_qabs\&u=\%23p\% $\underline{\text { 3D87iLXFbX gEJ }}$

https://ejournal.upi.edu/index.php/jpmanper/article/view/3264

Pembelajaran Kontekstual https://www.google.com/url?sa=t\&source=web\&rct=j\&url=https://eprints. uny.ac.id/25714/2/BAB\%2520II.pdf\&ved=2ahUKEwipxuzHw8_0AhWD SWwGHei4CucQFnoECAQQBg\&usg=AOvVaw319Kic6pObXTSP9WvRuQd 


\section{*Data Penulis}

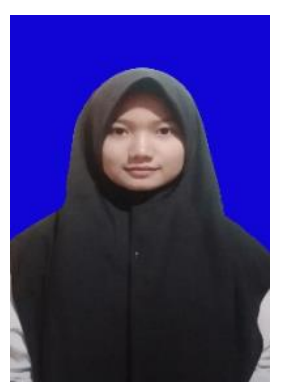

Mia Audina, lahir di Duri, 2 Mei 2002. Pada tahun akademik 2020sekarang, Ia melanjutkan studi pada strata satu Jurusan Pendidikan Bahasa dan Seni di Program Studi Pendidikan Bahasa dan Sastra Indonesia FKIP Universitas Riau melalui jalur SMMPTN-BARAT (Seleksi Mandiri Masuk Perguruan Tinggi Negeri-Bagian Barat), awal mulanya saya tidak memilih jurusan ini dikarenakan dulu saya tamatan SMK dan saya berniat untuk melanjutkan di Perguruan Tinggi. Namun, karena nilai saya yang tidak mencukupi untuk masuk teknik, dan untuk jalur SMMPTN-BARAT ini diberikan tiga jurusan untuk dipilih, alhamdulillah saya diterima dimata pelajaran yang saya sukai yaitu Bahasa Indonesia. Karena saya sudah terlanjur berkuliah di jurusan ini, juga mengingat biaya yang dikeluarkan untuk mengkuliahkan saya, saya bertekat untuk serius di jurusan ini.

\section{Kontak:}

Hp/WA : 082283219059

Email : mia.audina5811@student.unri.ac.id 